\title{
Makna Dalam Mantra Pengobatan Etnis Tionghoa Marga Lay Kota Singkawang
}

\author{
Fitri $^{1}$, Mardian $^{2}$ \\ Program Studi Pendidikan Bahasa dan Sastra Indonesia, (STKIP) Singkawang, \\ E-mail: fitri_djayadi@yahoo.co.id, mardiandeeza@gmail.com
}

\author{
Keywords : \\ makna; mantra mengobatan; \\ Marga Lay
}

\begin{abstract}
Penelitian ini dilatarbelakangi oleh keinginan penulis untuk mengetahui makna mantra yang digunakan oleh masyarakat Tionghoa, khususnya marga Lay yang berada di Kota Singkawang. Masalah dalam penelitian ini adalah "Bagaimanakah makna dalam Mantra Pengobatan Etnis Tionghoa Marga Lay di Kota Singkawang?" Tujuan penelitian ini untuk mendeskripsikan makna dalam mantra pengobatan etnis Tionghoa Marga Lay di Kota Singkawang. Manfaat penelitian ini ialah untuk menambah ilmu pengetahuan yang berkaitan dengan bidang semantik karya sastra khususnya pada mantra. Metode penelitian yang digunakan dalam penelitian ini, yakni metode deskriptif. Bentuk penelitian yang digunakan yakni bentuk kualitatif. Data dalam penelitian ini adalah semua kutipan mantra yang terdapat dalam mantra pengobatan etnis Tionghoa marga Lay di Kota Singkawang. Sumber data dalam penelitian ini adalah mantra pengobatan etnis Tionghoa Marga Lay di Kota Singkawang. Teknik yang digunakan dalam penelitian ini adalah teknik wawancara dan perekaman. Instrument utama dalam penelitian ini adalah peneliti sendiri dengan alat bantu yakni kartu pencatat data dari hasil perekaman data yang dilakukan. Teknik pengecekan keabsahan data menggunakan ketekunan pembacaan, kecukupan referensi, dan teknik triangulasi
\end{abstract}




\section{PENDAHULUAN}

Karya sastra merupakan hasil kreatif dari manusia yang dapat berbentuk lisan maupun tulis. Karya lisan merupakan karya yang biasanya akan berlangsung turun temurun dari mulut ke mulut. Di dalamnya terkandung nilai-nilai masyarakat yang dekat dengan penciptanya. Karya lisan dapat berupa cerita, puisi, syair, mantera, dan sebagainya. Sastra lisan biasanya lahir dari masyarakat yang bersifat tradisional, kental akan budaya dan lebih menekankan pada sifat khayalan yang magis. Sastra ini mempunya ciri-ciri gaya bahasa yang berlainan dengan sastra tulis meskipun tidak terlalu mencolok. Ciri-ciri khas yang berwujud pengungkapan alam pikiran masyarakat, norma hidup, nilai-nilai, tercakup dalam sastra lisan.

Karya lisan banyak juga yang muncul karena pengaruh perorangan, khususnya orang yang dikenal dan pandai di masyarakatnya. Selain untuk dinikmati, sastra lisan biasanya dapat berupa mantra yang dapat memberikan pengaruh terhadap pendengarnya. Mantra ini juga kadang diucapkan pada upacaraupacara tertentu. Mantra merupakan bagian dari puisi lama. Mantra adalah sebuah sastra lisan yang telah berkembang sejak zaman dahulu. Mantra dipercaya berhubungan dengan alam gaib, sejak dahulu, mantra telah digunakan dalam berbagai kalangan dan berbagai aspek. Mantra terbagi menjadi beberapa ragam yang sering diketahui di khalayak luas, antara lain sebagai mantra pengobatan, mantra pengasih, mantra tolak bala.

Mantra termasuk ke dalam kebudayaan masyarakat Tionghoa. Di Kota Singkawang masyarakat Tionghoa menggunakan bahasa Hakka sebagai bahasa sehari-hari. Sebagai informasi tambahan, bahasa Hakka berbeda dengan bahasa mandarin yang digunakan di negara Tiongkok. Bahasa Hakka adalah bahasa yang digunakan oleh masyarakat Tionghoa di kota Singkawang. Bahasa Hakka sering disebut juga bahasa Khek, yang artinya sama, yakni bahasa yang digunakan oleh masyarakat Tionghoa di kota Singkawang. Sedangkan bahasa mandarin adalah bahasa dari suku Han yang berada di negara Tiongkok. Bahasa mandarin digunakan di Kota Singkawang hanya dalam mata pelajaran sekolah di jenjang tertentu saja, tidak seperti bahasa Hakka yang dipergunakan dalam kehidupan sehari-hari. Mantra dalam bahasa Hakka disebut Ciang Syin, mantra dalam bahasa tersebut adalah mantra yang jarang ditemukan dalam kehidupan modern seperti sekarang. Di kota-kota besar sudah jarang mempercayai mengenai mantra, terutama dalam bahasa Hakka. Namun, kota Singkawang kepercayaan akan mantra masih melekat meskipun hidup di zaman modern. Banyak yang berobat pergi ke dukun, tabib, atau Sinsang yang biasanya menggunakan mantra sebagai cara pengobatan. Sinsang adalah orang yang ahli dalam mengobati penyakit seseorang. Kota Singkawang adalah kota yang dihuni oleh berbagai suku, satu diantaranya adalah suku Tionghoa. Dengan adanya suku Tionghoa inilah yang menciptakan kepercayaan terhadap mantra yang berasal dari dewa-dewa langit. Kepercayaan masyarakat Tionghoa terhadap mantra sangat kental dibanding dengan suku-suku lain.

Kota Singkawang, khususnya dalam masyarakat Tionghoa kepercayaan akan mantra tercipta dengan adanya Sinsang. Sinsang merupakan orang yang menguasai mantra khususnya dalam bahasa hakka. Dengan adanya sinsang inilah yang menjadi sosok pembaca mantra dalam segala kebutuhan. Misalnya untuk pengobatan, pekerjaan, tolak bala, perdagangan atau pembacaan mantra dalam festival atau ritual tertentu. Kehadiran mantra ini dipercaya masyarakat dapat memenuhi kebutuhan yang sedang dihadapinya. Mantra masih sering digunakan oleh masyarakat karena mereka percaya bahwa mantra dapat membantu memecahkan permasalahan yang tidak dapat dipecahkan secara logis. Pola pikir yang seperti inilah yang menjadikan mantra sebagai alat bantu untuk memperlancar sesuatu yang diinginkan.

Mantra yang sering diucapkan sinsang adalah mantra yang berkaitan dengan kesembuhan atau pengobatan. Mantra pengobatan adalah mantra yang dipercaya sebagai rangkaian kata atau kalimat yang berkekuatan gaib berguna untuk penyembuhan segala penyakit bagi orang yang 
mempercayainya. Di kota Singkawang, masyarakat percaya dengan penyembuhan tradisional dengan metode pembacaan mantra dan ritual sesajen yang dilakukan oleh sinsang.Banyak masyarakat yang datang ke vihara/klenteng kepercayaan mereka untuk mendapat pengobatan langsung dari sinsang, dan diakhiri dengan memberikan imbalan atas jasa yang telah dilakukan sinsang kepadanya.

Adanya mantra pengobatan yang ada di kota Singkawang dipercaya sebagai wujud dari bantuan dewa yang disampaikan melalui perantara yakni sinsang. Menurut kepercayaan etnis Tionghoa di Singkawang, dewa dewi yang telah menolong mereka dari segala penyakit harus diberi sebuah penghargaan berupa pemberian sesajen yang sekiranya diperlukan oleh dewa dewi. Menurut keyakinan orang hakka, dewa dewi itu tidak ubahnya seperti manusia, mereka dapat merasa lapar, haus, panas dan dingin (Tanggok, 2017 : 32). Maka dari itulah, pemberiaan sesajen setelah pengobatan diperlukan sebagai imbalan untuk dewa dewi yang telah membantu.

Pada saat membacakan mantra, sinsang tidak dapat langsung membacakannya dengan begitu saja. Sinsang harus dirasuki oleh dewa dan berkomunikasi dengan dewa tersebut untuk membacakan mantra sesuai dengan kebutuhan pada saat itu. Menurut kepercayaan sinsang, ketika akan membacakan mantra beliau akan menggunakan bahasa alam gaib/bahasa dewa yang dimengerti oleh dirinya sendiri dan penerjemah bahasa gaib/bahasa dewa tersebut. Bahasa tersebut kemudian diartikan dan dibacakan ulang dengan menggunakan bahasa hakka, yang dimengerti oleh masyarakat Tionghoa Singkawang. Dalam keadaan tidak sadar itulah sinsang membacakan mantra sebagai alat membantu memecahkan masalah dari klien yang datang padanya. Mantra dalam bahasa hakka ini sangat khas karena bahasa yang digunakan berbeda dengan mantra yang digunakan masyarakat pada umumnya.

\section{KAJIAN TEORI}

Karya sastra tulis biasanya menghasilkan karya yang lebih mudah untuk dilihat dan ditemukan. Karya tulis ini bentuknya biasa sama dengan karya lisan, namun bentuknya dapat dilihat dan dipegang. Pada saat ini, karya tulis dapat ditemukan dalam bentuk buku. Adapun fokus dalam penelitian ini yakni berkaitan dengan sastra lisan, yakni mantra. Sastra lisan adalah karya sastra yang penyebarannya disampaikan dari mulut ke mulut secara turun temurun (Endraswara, 2008:150). Sastra lisan juga kadang sejalan dan dapat dikatakan sebagai tradisi lisan, karena sastra lisan berkembang berdasarkan tradisi yang ada di masyarakat.

Sastra lisan merupakan suatu dunia yang lapang, dunia yang melibatkan banyak orang, dunia untuk banyak orang dalam arti kata sebenarnya (Amir, 2013:75). Sastra lisan mnceritakan manusia dan disampaikan oleh manusia. Dapat disimpulkan bahwa sastra lisan memerlukan orang lain, sebagai sarana penyampaian maupun sebagai penikmat dari karya sastra tersebut. Sastra lisan hidup ditengah masyarakat yang tradisional, yang hidup dalam suasana lisan, yang tidak membaca, yang bahkan buta huruf. Kedua, sastra lisan berwujud dan dinikmati secara lisan di antara masyarakatnya. Ketiga, diwariskan secara lisan. Keempat, sastra lisan menggunakan ungkapan-ungkapan yang berulang-ulang (Amir, 2013 : 10).

Sastra lisan adalah kesusastraan yang mencakup ekspresi kesusastran warga suatu kebudayaan yang disebarkan dan diturun-temurunkan sastra lisan (dari mulut ke mulut). Sedangkan sastra tulis berupa karya sastra yang dicetak atau ditulis (Astika dkk, 2014 : 2). Bentuk sastra lisan yang ada di masyarakat adalah pantun, syair, seloka, gurindam, mantra, prosa liris, hikayat. Jadi, dapat disimpulkan bahwa karya sastra baik lisan maupun tulis sama-sama lama hadir di kalangan masyarakat, dan masing-masing mempunyai nilai estetik.

Ciri-ciri sastra lisan menurut (Astika dkk, 2014 : 4) adalah sebagai berikut ; Ciri pertama sastra lisan, yaitu cara penyampaian atau penyebarannya. Ciri kedua, yaitu bersifat kolektif. Ciri ketiga, yaitu 
bersifat anonim. Ciri keempat, yaitu bersifat tradisional. Ciri kelima, yaitu memiliki berbagai versi. Ciri keenam, yaitu memiliki kegunaan/fungsi tertentu dalam masyarakat. Ciri ketujuh, yaitu memiliki bentuk/pola/formula yang tertentu. Ciri kedelapan, yaitu memiliki sifat-sifat sastra, yaitu bermediumkan bahasa, fiksi atau tidak nyata/khayalan, imajinatif, bahasa yang indah/puitis, fungsi estetis dan berguna.

Dapat dikatakan perbedaan antara sastra dan lisan terdapat pada media yang membawanya terhadap manusia lain.

Menurut Hutomo (dalam Rafiek, 2010 : 54) bahan sastra lisan dapat dibedakan menjadi tiga bagian, yaitu (1) bahan yang bercorak cerita seperti (a) cerita-cerita biasa, (b) mitos, (c) legenda, (d) epik, (e) cerita tutur, (f) memori; (2) bahan yang bercorak bukan cerita seperti (a) ungkapan, (b) nyanyian, (c) peribahasa, (d) teka-teki, (e) puisi lisan, (f) nyanyian sedih pemakaman, (g) undang-undang atau peraturan adat; (3) bahan yang bercorak tingkah laku (drama) seperti (a) drama panggung dan (b) drama arena. Dari penjelasan di atas dapat disimpulkan bahwa sastra lisan merupakan tradisi yang ada di masyarakat, yang bersifat primer dan sekunder. Tradisi lisan ini beragam corak, disesuaikan dengan sastra yang berada di tengah masyarakat pemakainya.

Mantra merupakan satu di antara sastra lisan yang banyak mengandung nilai-nilai luhur dan unsur budaya yang tinggi. Mantra biasanya muncul didasarkan pada tempat dan tujuan tertentu. Biasanya terdapat unsur magis di dalamnya. Hal ini menyebabkan terkadang bahasa mantra sulit dipahami oleh masyarakat awam. Pemantralah yang memahami apa yang disampaikannya. Di samping itu, mantra memiliki unsur mitos yang terdapat dalam kehidupan masyarakat. Mitos pasti memiliki landasan historis, baik mitos yang kuno maupun yang tidak, karena dia adalah tipe wicara yang dipilih oleh sejarah. Dapat dikatakan mitos pasti memiliki nilai historis yang berkaitan dengan penciptaannya. Sastra klasik atau bisa disebut pula sebagai sastra lama atau sastra tradisional adalah karya sastra yang tercipta dan berkembang sebelum masuknya unsur-unsur modernisme ke dalam sastra itu (Kosasih, 2012 : 13). Hal ini menyebabkan sastra klasik masih dapat dikatakan murni milik masyarakatnya.

Pengertian sastra lama juga dikemukakan oleh (Yuli, 2017: 1), menurutnya sastra lama tumbuh dan berkembang dalam masyarakat lama yang bersifat statis. Dikatakan stastis karena gerak gerik masyarakat lama sangat dipengaruhi oleh kepercayaan, seperti animisme, dinamisme, hinduisme, dan islamisme. Jadi, sastra lama merupakan jenis sastra yang telah berkembang pada masyarakat sejak zaman dahulu.

Mantra merupakan satu di antara sastra klasik sehingga dianggap sebagai awal bentuk sastra klasik. Mantra merupakan bentuk puisi yang berupa gubahan yang diresapi oleh kepercayaan tentang dunia gaib. Mantra juga dapat dikatakan sebagai kumpulan kata atau bunyi yang berkekuatan gaib, diucapkan secara berirama seperti senandung. Kadang digunakan sebagai doa oleh pengucapnya, sehingga harus diucapkan dengan tepat sehingga tidak terjadi kesalahan arti. Fungsi mantra dapat digunakan untuk menyembuhkan penyakit, mendatangkan kebaikan dan celaka, mengusir makhluk halus, dan sebagainya. Mantra biasanya dilafalkan dengan pelan-pelan, bahkan kadang diucapkan dalam batin. Di dalam mantra juga terkandung pesan, sugesti, larangan yang menuju ke titik mistik/gaib.

Bahasa yang digunakan dalam mantra biasanya memiliki makna magis tersendiri. Bahasa yang digunkan dalam mantra sukar dipahami, maka dari itu mantra memiliki bahasa khusus. Mantra biasanya menggunakan bahasa Arab, bahasa Jawa, bahasa Melayu, dan bahasa campuran lainnya, tergantung di mana tempat iru berkembang. Mantra dianggap sebagai kalimat permohonan dan pemujaan kepada Tuhan, atau ada juga yang ditujukan kepada makhluk halus guna dimintai bantuan. Masyarakat percaya bahwa sebuah mantra memiliki kekuatan gaib atau daya magis. Sehingga masyarakat lebih percaya akan mantra daripada perawatan medis, jika menderita suatu penyakit. 
Menurut kepercayaan orang Tionghoa di kota Singkawang, singsang merupakan orang yang dipercayai sebagai dokter kedua dalam mengobati penyakit yang tidak hanya penyakit biasa, namun penyakit yang disebabkan oleh roh-roh halus. Mantra didaraskan atas permintaan seseorang. Pendaras mantra yang mengobati dan membacakan mantra di sebut tabib atau sinsang. Sinsang adalah orang yang ahli mengobati dan meramal nasib seseorang (Tanggok, 2017:57).

Makna adalah arti dari kata atau morfem yang terdapat di dalamnya, maksud yang terkandung dalam sebuah teks. Makna adalah segi yang menimbulkan reaksi dalam pikiran pendengar atau pembaca karena rangsangan aspek bentuk (Keraf, 2010: 25). Dapat dikatakan makna adalah maksud dari kata atau kalimat dalam mantra, yang dapat menimbulkan reaksi dari pendengar atau pembaca penikmat karya sastra. Dalam penelitian ini makna yang akan diteliti berkaitan dengan makna denotatif dan makna konotatif.

Makna denotatif adalah makna sebenarnya. Makna yang lazim diberi penjelasan sebagai makna yang sesuai dengan kenyataan yang ada, menurut penglihatan, penciuman, pendengaran, perasaan, atau pengalaman lainnya (Chaer, 2009:66). Dengan kata lain, makna ini merupakan arti yang jelas dari sebuah kata. Makna denotatif adalah makna yang menunjukkan adanya hubungan antara konsep dengan dunia kenyataan (Djajasudarma, 2010 : 11). Artinya, makna makna denotatif atau makna kognitif adalah makna yang sebenarnya, yang dapat dilihat, dicium, didengar dan dapat dirasakan. Pendapat tersebut diperkuat dengan pernyataan. Makna denotatif adalah makna asli, makna asal, atau maka sebenarnya yang dimiliki oleh sebuah leksem (Chaer, 2012 : 292). Jadi, makna denotatif ini merupakan makna asli dari sebuah kata.

Makna konotatif muncul sebagai akibat asosiasi perasaan kita terhadap apa yang diucapkan atau apa yang didengar (Djajasudarma, 2010 : 12). Makna konotatif adalah sebuah kata yang dapat berbeda dari satu kelompok masyarakat yang satu dengan kelompok masyarakat yang lain, sesuai dengan pandangan hidup dan norma-norma penilaian kelompok masyarakat tersebut (Chaer : 2009 : 69). Dapat dikatakan makna konotatif ini bergantung pada situasi emosional manusia.

Makna konotatif tentu saja berkaitan dengan pilihan kata yang digunakan oleh penulis. Keraf (2010 : 24) membuat kesimpulan mengenai diksi, yaitu : (1) pilihan kata atau diksi mencakup pengertian katakata mana yang dipakai untuk menyampaikan suatu gagasan, bagaimana membentuk pengelompokkan kata-kata yang tepat untuk menggunakan ungkapan-ungkapan yang tepat, dan gaya mana yang paling baik digunakan dalam situasi, (2) pilihan kata atau diksi adalah kemampuan secara tepat nuansanuansa makna dari gagasan yang ingin disampaikan, dan kemampuan untuk mengemukakan bentuk yang sesuai (cocok) dengan situasi dan nilai rasa yang dimiliki kelompok masyarakat pendengar, (3) pilihan kata yang tepat dan sesuai hanya dimungkinkan oleh penguasaan sejumlah besar kosa kata atau pembendaharaan kata atau kosa kata suatu bahasa adalah keseluruhan kata yang dimiliki oleh sebuah bahasa. Dapat dikatakan makna ini disesuaikan dengan perasaan penulisnya.

\section{METODE PENELITIAN}

Metode yang digunakan dalam penelitian ini ialah metode deskripsi dengan bentuk kualitatif. Pendekatan yang digunakan ialah pendekatan strukturalisme. Sumber data dalam penelitian ini adalah rekaman mantra pengobatan dalam bahasa Hakka etnis Tionghoa Singkawang, peneliti langsung terjun ke lapangan merekam mantra yang langsung diucapkan oleh Sinsang. Berlokasi di Malindo Teluk Karang, Kelurahan Sedau, Kecamatan Singkawang Selatan, Kota Singkawang. Adapun datanya berupa transkripsi data hasil rekaman mantra yang diucapkan oleh Sinsang. Kemudian data tambahan berupa terjemahan yang langsung diterjemahkan oleh ahlinya, yakni informan. Teknik penelitian dalam penelitian ini yakni teknik wawancara dan perekaman. Alat pengumpul data yakni alat perekam 
(audio visual) yang berikutnya diklasifikasikan menggunakan kartu data dan dilakukan analisis. Pengecekan keabsahan dilakukan dengan ketekunan pembacaan, kecukupan referensi dan teknik triangulasi.

\section{HASIL PENELITIAN}

Makna merupakan maksud yang terkandung dalam teks. Untuk menganalisis mantra pengobatan etnis Tionghoa marga Lay, peneliti menggunakan jenis makna yang dilihat berdasarkan ada atau tidaknya nilai rasa dalam sebuah kata, makna tersebut yaitu, (1) makna denotatif adalah kata yang mempunyai makna sebenarnya. (2) makna konotatif adalah kata yang bukan arti sebenarnya. Makna konotatif biasanya mempunyai makna tambahan. Penerapan makna donatatif dan makna konotatif dalam mantra pengobatan masyarakat Tionghoa marga Lay, sebagai berikut:

\section{Mantra I}

Mantra Penyembuhan orang dewasa dari gangguan makhluk halus

(1/3) Choi ton cung ali, jiu ton cang pun nyi,

'di altar ini kami undang untuk datang dan kami beri tahu untuk menerima,'

Kalimat dalam data (1/3) mengandung makna konotasi. Dikatakan makna konotasi, karena dalam kalimat tersebut mengandung kalimat yang ambigu atau makna yang disampaikan belum jelas. Kata 'undang' harus diberi makna tambahan (siapa yang diundang) agar kalimat tersebut dapat dipahami pembaca.

\section{(1/6) Ciung ki nyit}

'mulai hari ini'

Penggunaan kalimat dalam mantra pengobatan etnis tionghoa pada data (1/6) merupakan makna konotasi. Artinya, kalimat tersebut bukan makna yang sebenarnya. Kalimat 'mulai hari ini' masih bisa ditafsirkan dengan kalimat lain, sehingga makna sebenarnya akan tampak.

\section{Mantra II}

Mantra Penyembuhan anak kecil dari gangguan makhluk halus di malam hari.

a. Makna Denotatif

Pemanfaatan kalimat denotatif dalam mantra penyembuhan anak kecil dari gangguan makhluk haluspada malam hari, terlihat sebagai berikut,

(2/2) Pak kung, pak po

'dewa malam dan dewi mimpi'

Data (2/1) termasuk ke dalam kalimat yang bermakna denotasi. Dikatakan demikian karena kalimat tersebut menyatakan kepada siapa mantra itu ditujukan, yakni kepada dewa malam dan dewi mimpi. Kalimat tersebut bermakna denotasi, karena kalimat tersebut mempunyai makna sebenarnya, tanpa ada kata tambahan untuk menafsirkan kalimat tersebut.

b. Makna Konotatif

Pemanfaatan kalimat konotatif dalam mantra penyembuhan anak kecil dari gangguan makhluk haluspada malam hari, terlihat sebagai berikut,

(2/1) Ciung ki nyit, kin pu ja

'mulai hari ini dan malam ini'

Kalimat dalam data (2/1) merupakan kalimat yang bermakna konotasi. Dikatakan bermakna konotasi karena kalimat tersebut bukan makna yang sebenarnya, artinya kalimat tersebut harus ditambah beberapa kata agar kalimat tersebut dapat ditafsirkan menjadi makna yang sebenarnya.

Mantra III

Mantra pengobatan untuk menguatkan kandungan hingga selamat saat melahirkan.

a. Makna Denotatif

Pemanfaatan kalimat denotatif dalam mantra pengobatan untuk menguatkan kandungan hingga selamat saat melahirkan.

terlihat sebagai berikut,

(3/2) Kon jim fut mu papit thong cit

'wahai dewi kwan im, kami telah hadir' 
Data (3/2) merupakan kalimat yang bermakna denotasi. Dikatakan bermakna denotasi karena kalimat tersebut sudah dapat ditafsirkan. Dalam kalimat tersebut dapat diartikan bahwa pemantra memanggil dewi kwan im dan beliau mengatakan bahwa dirinya dan pasien telah hadir, menunggu kedatangan dewi kwan im. Data (3/2) tersebut tidak memerlukan kata tambahan untuk mengartikan makna keseluruhan dalam kalimat.

b. Makna Konotatif

Pemanfaatan kalimatkonotatif dalam mantra pengobatan untuk menguatkan kandungan hingga selamat saat melahirkan, terlihat sebagai berikut,

\section{(3/1) Nyit nyat sam kong}

'hari yang baik ini kami minta dari tiga alam'

Data (3/1) merupakaan kalimat yang bermakna konotasi. Kalimat dalam data (3/1) tidak dapat ditafsirkan dengan jelas. Kata 'kami minta dari tiga alam' masih mengandung pertanyaan, apa yang diminta dari tiga alam tersebut. Jadi, kalimat dalam data (3/1) masih memerlukan kata lain agar kalimat tersebut dapat ditafsirkan (makna konotasi).

\section{Mantra IV}

Mantra pengobatan untuk menghilangkan guna-guna atau terkena santet

a. Makna Denotasi

Pemanfaatan kalimat denotasi dalam mantra pengobatan untuk menghilangkan guna-guna atau terkena santet, terlihat sebagai berikut,

(4/4) Loi kak nyi se fa syui

'akan memandikan kamu dengan bunga-bunga'

Kalimat dalam data (4/4) merupakan data yang bermakna denotasi. Dikatakan demikian, karena data tersebut sudah dapat ditafsirkan maknanya. Artinya, sudah diketahui makna sebenarnya. Kalimat 'akan memandikan kamu dengan bunga-bunga', bearti sudah jelas bahwa pemantra akan memandikan pasiennya dengan sesajen yang berupa bunga-bunga.

b. Makna Konotatif

Pemanfaatan kalimat konotatif dalam mantra pengobatan untuk menghilangkan guna-guna atau terkena santet, terlihat sebagai berikut,

\section{(4/1) Ciung ki nyit}

'mulai hari ini'

Data (4/1) merupakan kalimat yang bermakna konotasi. Dikatakan demikian, karena dalam kalimat tersebut belum dapat ditafsirkan dan diketahui makna sebenarnya. Kalimat ciung ki nyit 'mulai hari ini' masih memerlukan tambahan kata lain agar diketahui apa maksud yang sebenarnya dari kalimat tersebut.

\section{Mantra V}

Mantra pengobatan untuk menghilangkan sakit dibagian dada akibat terkena makhluk halus.

a. Makna Denotasi

Pemanfaatan kalimat denotatif dalam mantra pengobatan untuk menghilangkan sakit dibagian dada akibat terkena makhluk halus, terlihat sebagai berikut,

\section{(5/3) Pak kung pak po co cin min}

'dewa langit dan dewi bumi turut menyaksikan'

Kalimat dalam data (5/3) dapat digolongkan sebagai kalimat yang bermakna denotasi. Dalam kalimat tersebut diartikan dewa langit dan dewi bumi turut menyaksikan. Jadi, sudah diketahui makna sebenarnya, bahwa pada saat pembacaan mantra ada dewa langit dan dewi bumi yang menyaksikan. Kalimat tersebut sudah dapat ditafsirkan tanpa harus ditambah dengan kata lain.

b. Makna Konotatif

Pemanfaatan kalimatkonotatifdalam mantra pengobatan untuk menghilangkan sakit dibagian dada akibat terkena makhluk halus, terlihat sebagai berikut,

\section{(5/1) Ciung ki nyit}

'Mulai hari ini'

Data (5/1) merupakan kalimat yang bermakna konotasi. Dikatakan demikian, karena dalam kalimat tersebut belum dapat ditafsirkan dan diketahui makna sebenarnya. Kalimat ciung ki nyit ${ }^{6}$ mulai 
hari ini' masih memerlukan tambahan kata lain agar diketahui apa maksud yang sebenarnya dari kalimat tersebut.

\section{Mantra VI}

Mantra Pengobatan untuk anak kecil yang demam pada malam hari.

a. Makna Denotasi

Pemanfaatan kalimat denotatif dalam mantra pengobatan untuk untuk anak kecil yang demam pada malam hari, terlihat sebagai berikut,

(6/1) Ciung ki nyit puja

'mulai malam ini juga'

Data (6/1) merupakan kalimat yang bermakna denotasi. Dikatakan demikian karena sudah jelas bahwa pada saat pembacaan mantra dilakukan pada malam hari. Sudah diketahui makna sebenarnya. Tanpa memerlukan kalimat penjelas yang lain.

b. Makna Konotasi

Pemanfaatan kalimat konotasi dalam mantra pengobatan untuk untuk anak kecil yang demam pada malam hari, terlihat sebagai berikut,

(6/3) Choi li ha ham nya fun con

'mulai sekarang kami minta agar dia tidak lagi panas pada malam hari'

Data (6/3) merupakan kalimat yang bermakna konotasi. Dikatakan demikian karena data tersebut tidak dapat ditafsirkan secara jelas. Dalam kalimat tersebut diminta bahwa pasien tidak akan sakit demam panas lagi. Kalimat tersebut masih tidak dapat dipastikan kebenarannya. Karena bisa saja pada malam selanjutnya pasien mengalami demam panas kembali. Jadi, disimpulkan bahwa kalimat tersebut tergolong bermakna konotasi.

\section{Mantra VII}

Mantra pengobatan untuk orang dewasa yang sakit kepala akibat terkena hujan panas.

a. Makna Denotasi

Pemanfaatan kalimat denotasidalam mantra pengobatan untuk orang dewasa yang sakit kepala akibat terkena hujan panas, terlihat sebagai berikut,

\section{(7/2) Sai pho sen kiun co cin min}

'dewa penyembuh jadi saksi'

Kalimat dalam data (7/3) dapat digolongkan sebagai kalimat yang bermakna denotasi. Dalam kalimat tersebut diartikan dewa penyembuh jadi saksi. Jadi, sudah diketahui makna sebenarnya, bahwa pada saat pembacaan mantra ada dewa penyembuh yang menyaksikan. Kalimat tersebut sudah dapat ditafsirkan tanpa harus ditambah dengan kata lain.

\section{b. Makna Konotasi}

Pemanfaatan kalimat konotasidalam mantra pengobatan untuk orang dewasa yang sakit kepala akibat terkena hujan panas, terlihat sebagai berikut,

\section{(7/1) Ciung ki nyit}

'mulai hari ini'

Data (7/1) merupakan kalimat yang bermakna konotasi. Dikatakan demikian, karena dalam kalimat tersebut belum dapat ditafsirkan dan diketahui makna sebenarnya. Kalimat ciung ki nyit ${ }^{6}$ mulai hari ini' masih memerlukan tambahan kata lain agar diketahui apa maksud yang sebenarnya dari kalimat tersebut.

\section{Mantra VIII}

Mantra pengobatan untuk orang dewasa yang sakit kepala akibat terkena hujan panas.

a. Makna Denotasi

Pemanfaatan kalimat denotasidalam mantra pengobatan untuk orang dewasa yang sakit mata terlihat sebagai berikut,

\section{(8/2) Soi pho sen kiun co cin min}

'dewa penyembuh jadi saksi

Kalimat dalam data (8/2) dapat digolongkan sebagai kalimat yang bermakna denotasi. Dalam kalimat tersebut diartikan dewa penyembuh jadi saksi. Jadi, sudah diketahui makna 
sebenarnya, bahwa pada saat pembacaan mantra ada dewa penyembuh yang menyaksikan. Kalimat tersebut sudah dapat ditafsirkan tanpa harus ditambah dengan kata lain.

b. Makna Konotasi

Pemanfaatan kalimat denotasidalam mantra pengobatan untuk orang dewasa yang sakit mata terlihat sebagai berikut,

(8/1) Ciung ki nyit

'mulai hari ini'

Data (8/1) merupakan kalimat yang bermakna konotasi. Dikatakan demikian, karena dalam kalimat tersebut belum dapat ditafsirkan dan diketahui makna sebenarnya. Kalimat ciung ki nyit ${ }^{6}$ mulai hari ini' masih memerlukan tambahan kata lain agar diketahui apa maksud yang sebenarnya dari kalimat tersebut.

\section{SIMPULAN}

Berdasarkan penelitian yang telah dilakukan, dapat disimpulkan bahwa makna dalam mantra pengobatan etnis Tionghoa di kota Singkawang yang dianalisis berdasarkan jenis makna dilihat berdasarkan ada atau tidaknya "nilai rasa" dalam sebuah kata maupun kalimat. Makna tersebut ialah, makna denotatif (makna sebenarnya) dan makna konotatif (bukan makna sebenarnya). Setelah menganalisis delapan mantra pengobatan etnis Tionghoa Singkawang, ditemukan 55 data bermakna denotasi dan 43 mantra bermakna konotasi. Artinya, dalam keseluruhan mantra pengobatan etnis Tionghoa Singkawang memiliki lebih banyak arti kata yang sebenarnya (denotatif) dibandingkan dengan kata yang tidak diketahui makna sebenarnya (konotatif).

\section{Daftar Pustaka}

Amir, Adriyetti. 2013. Sastra Lisan Indonesia. Yogyakarta : Andi.

Chaer, Abdul. 2009. Semantik Bahasa Indonesia. Jakarta :Rineka Cipta.

- . 2012. Linguistik Umum. Jakarta : Rineka Cipta.

Endraswara, Suwardi. 2013. Metodologi Penelitian Sastra : Epistemologi, Model, Teori dan Aplikasi. Yogyakarta : Gadjah Mada University University Press.

Keraf, Gorys. 2010. Diksi dan Gaya Bahasa. Jakarta : PT Gramedia Pustaka Utama.

Pradopo, Rachmat Djoko. 2012. Pengkajian Puisi. Yogyakarta : Gadjah Mada University Press.

Rafiek. 2012. Teori sastra : Kajian Teori dan Praktik. Bandung : Refika Aditama.

Rahmayani, Any. 2014. Permukiman Tionghoa Di Singkawang. Yogyakarta : Ombak.

Semi, Attar. 2012. Metode Penelitian Sastra. Bandung : Angkasa.

Tanggok, Ikhsan. 2017. Agama dan Kebudayaan Orang Hakka di Singkawang: Memuja Leluhur dan Menanti Datangnya Rezeki. Jakarta : Kompas. 